\title{
Light and scanning electron microscope studies on the nematode Aplectana macintoshii Travassos,1931(Ascaridida:Cosmocercidae) infecting the toad Bufo regularis in Egypt.
}

\author{
Amira I. El Kabbany ${ }^{1}$, Hala A. Abdel salam ${ }^{2}$ and \\ Hesham M. Sharaf ${ }^{1}$ \\ 1-Department of Zoology, Faculty of Sci., Zagazig Univ., Zagzig, Egypt. \\ 2- Department of zoology, Faculty of Sci., Cairo Univ., Giza, Egypt.
}

\begin{abstract}
A plectana macintoshii Travassos,1931 from the intestine of Bufo regularis - was described and illustrated. A. macintoshii adult worms are small dieocious nematodes. Males are distinguishable from females by their smaller size, long slender curved posterior end and accessory copulatory structures with two equal spicules. Cuticle with longitudinal and circular annulations and somatic papillae. Mouth is small opening surrounded by three lips. Each lip bears two conspicuous papillae. The alimentary canal is composed of mouth that leads to oesophageal corpus, oesophageal bulb, intestine and rectum. The reproductive system of $A$. macintoshii is tubular. Females have two genital tubes that are distinguished into two ovaries, oviducts, uteri which join to form a single vagina which opens to the exterior through the vulva that lies near the anterior end of the body. The male genital tube consists of a blind-ending testis, seminal vesicle, vas deferens and the ejaculatory duct which opens into the rectum via the cloaca. The genital tubes of these parasitic nematoades are twisted around the intestine.
\end{abstract}

Keyword: Bufo regularis, Aplectana macintoshii, electron microscope, nematode

\section{INTRODUCTION}

The nematodes make up a large assemblage of relatively simple structure worms with a wide spread distribution, where their cylindrical non segmented bodies distinguish them easily from other helminthes (Levine, 1980). They occur in fresh water, in the sea and in soil and or in animals (Wharton,1986). The bilaterally symmetrical body of nematodes is covered by a typical cuticle. Their size is limited by the fact they do not possess circulatory system to accelerate the transport of nutrients to various organs. The alimentary canal and gonads are surrounded by a fluid-filled pseudocole which is not septate (Gibbons, 1986; Anderson,1988).

In many nematodes, the genital tubes are twisted around the intestine. The alimentary canal may be subdivided in nematodes into mouth, buccal cavity, oesophagus, intestine, rectum and anus (Smyth,1994; Ramallo et al., 2008). 
Furthermore, nematodes in general are dioecious, but relatively few species are hermaphorodites ( Perry \& Clark,1981; Smyth,1994).

Genus Aplectana (order: Ascaridia, family: Cosmocercidae) was erected by Railliet\& Henry (1916). It was previously named as Aplecta that was found to be preoccupied and so Aplectana was established as the replacement name (Railliet\& Henry,1916). Baker (1980) revised the genus and provided a key to 32 species; later in 1987, he assigned 39 species to this genus; four additional species have since been described (Bursey et al. 2006; Ramallo et al., 2008 and Ramalho et al., 2009).

Species of Aplectana are cosmopolitan in geographical distribution (Ragoo\&Maharaj, 2003; Yildirimhan et al., 2005; Bursey \& Goldberg, 2007; Holmes et al., 2008 and Ramalho et al.,2009) and their infection capability is not restricted to amphibians and reptiles since some of them are also capable of parasitizing salamanders and even fish (Rago \& Maharaj, 2003; Saeed et al.,2007 and Bursey \& Goldberg, 2007). However, studying scanning and ultrastructure of this nematode remains poor. Thus, the present study is an attempt to study the morphological details of Aplectana macnitoshii.

\section{MATERIAL AND METHODS}

The specimens of the nematode Aplectana macintoshii Travassos, 1931 were collected alive from the intestine of naturally infected Bufo regularis that were collected by large numbers from the Nile Delta, Egypt.

In the laboratory, the amphibian hosts were dissected, their intestines were examined carefully to collect the nematodes. The worms were washed in distilled water to render them free from any debris and rinsed quickly several times in normal saline solution. The nematodes were then observed under a compound microscope to confirm their taxonomic identification. The adult, worms were separated, dried on moist blotting paper and used for Scanning (SEM) electron microscopy studies. Specimens were fixated in a solution containing 4\% aqueous glutaraldehyde and 1\% osmium tetraoxide for 2 hours, briefly washed in distilled water, dehydrated in acetone, dried using CO2 critical point dryer, mounted on aluminium stubs and sputter coated with gold. Specimens were examined by JEOL scanning electron microscope.

Furthermore, many specimens were also prepared for detailed light microscopical examination. Worms, after being washed and fixed in $70 \%$ alcohol, were cleared in glycol and mounted in gely-glycerine on slides before further examination. All measurements were carried out by camera Lucida.

\section{RESULTS}

Aplectana macintoshii is a dioecious nematode, cuticle is not smooth, bearing longitudinal and circular striations and somatic papillae ( Fig. 1). The annulation extends over the whole body except for tips of head and tail. Annuli are not divided into subannuli (Fig. 2). The margins of the annuli are smooth, 
rounded and not overlapping throughout the length of the body. The body has a tapering anterior end and long slender like posterior end. The posterior region has a long curved distal end in male worms and a sharp pointed distal end in female ones (Figs. 3,6 \&7). On the anterior three quarters of the tail of male, anal papillae were observed (Fig.4). Each female is longer and wider than male. The female body length is 3.65 (3-5.2) $\mathrm{mm}$ and breadth $0.34(0.20-0.45) \mathrm{mm}$, while the male body length is1.50 (1.10-2-42) $\mathrm{mm}$ and its breadth $0.11(0.15$ $0.23) \mathrm{mm}$.

The alimentary tract in male and female worms begins with small mouth opening as an oval aperture surrounded by three lips, one dorsal and two ventrolateral (Fig.5). Each lip bears two conspicuous papillae. The mouth leads to long oesophgus distinguished into two portions, the first is the corpus that appears as long and narrow tube. It measures $0.3(0.30-0.40 \mathrm{~mm})$ in length and $0.049(0.043-0.061) \mathrm{mm}$ in breadth in female and $0.25(0.19-0.34) \mathrm{mm}$ in length and $0.02(0.02-0.20) \mathrm{mm}$ in breadth in male. The second portion is spherical in shape and called oesophageal bulb. It is 0.080 .(082-0.15) $\mathrm{mm}$ and $0.11(0.08-$ $0.15) \mathrm{mm}$ in length and breadth respectively in female, However it measures $0.41(0.039-0.052)$ in length and $0.049(0.039-0.060) \mathrm{mm}$ in male. The oesophageal bulb opens into a long intestine. The intestine extends posterior as a straight tube. The end of the alimentary tract opens onto the ventral surface of the parasite via cloaca in male or anus in female.

The excretory pore lies in the anterior half of the body at $0.92(0.86-0.12)$ $\mathrm{mm}$ in male and $0.35(0.30-0.40) \mathrm{mm}$ in female far from the mouth opening. It lies on the ventral surface of male worm and at the dorsal surface of the female.

The male reproductive system consists of a single long convoluted testis located in the middle third of the body and extends posteriorly forming a narrow and short vas deferens. The vas deferens widens forming a vesicula seminalis that opens in the ejaculatory duct. Both ends of the alimentary canal and the ejaculatory duct fuse together and open to the outside by the cloacal opening. At this opening, there are two equal sclerotized spear- shaped spicules which have pointed distal ends. Each spicule measures $0.28(0.20-0.31) \mathrm{mm}$ in length and 0.042(0.04-0.043) $\mathrm{mm}$ in breadth. (Fig. 6).

The female genital system consists of two long ovaries. Each ovary gives rise to a short oviduct which leads to a relatively wide uterus. The two uteri fuse together forming a muscular vagina that leads to a narrow slit-shaped vulva which lies at mid line of the body length where, it is situated at 1.94(1.822.00) $\mathrm{mm}$ from the anterior end of the body (Fig.7).

\section{DISCUSSION}

The presenly described nematode parasite species is evidently a member of the genus Aplectana (Railliet and Henry,1916), where it has the generic characters of Aplectana presented by Yamagui (1961) and Bursey \& Goldberg (2007). These characters are females of slightly greater length than males. 
Cuticle with longitudinal striations from oesophageal region to tip of tail and transverse striation (annulation) in the same region but most evident in posterior quarter of the body. The mouth with three lips, the execretory pore lies anterior to oesophageal bulb. Posterior extremity end bent venterally rapidly narrowing behind anus and ending in a pointed tail, very narrow caudal alae present in male, spicules equal usually slender. Female posterior extremity conical, pointed, vulva near the middle of the body.

These specific criteria led to suggest that the present species could be Aplectana macintoshii (Stewart, 1914), where, the present species resembles that of Travassos (1931) in body size of female, position of vulva, oesophageal bulb size, width of male and tail length of male. Furthermore, the present Aplectana parasite is more similar to that described from Bufo regularis in Cairo by Moravec et al.,(1987) and that of Farag (1995) in the same host in EL Mansoura in the body size of female, oesophageal length of male and female, position of excretory pore and length of spicules.

In comparsion to other Aplectana spp., it was observed that female of $A$. macintoshii is slightly larger in size than that of $A$. herediaensis (3.1 mm long \& 140 um wide) (Bursey et al.,2006) and that of A.krausi (3.05 mm long \& 234 um wide) (Bursey \&Goldberg, 2007) but smaller than that of A. artigasi (5.2 $\mathrm{mm} \&$ 414.9 um) (Puga \&Torres, 1997), and that of A. Capensis (6.4mm long)(Baker, 1981) and that of A. degraafi (4.1 mm long)(Baker,1981). Furthermore, the male A.macintoshii is smaller in size than that of other species like $A$. herediaensis ( $2.5 \mathrm{~mm}$ long \& $112 \mathrm{um}$ wide), A. artigasi (3.4mm long \& 322um wide), A.capensis (2.7mm long), A.degraafi (3.6mm long)and A.Krausi(2.53mm long \&152 um wide) as recorded by Bursey et al.,(2006), Puga \& Torres (1997) and Bursey \& Goldberg (2007).

Barker(1981) reported that $A$. capensis most closely resembles $A$. macintoshii and he distinguished these species from each other by the capitiulum of spicules in A.capensis that has the form of bulbous sclerotized cap which is not present in A. macintoshii Furthermore, the posterior half of the male tail in A. capensis lacks papillae whereas papillae occur on the anterior three quarters of the tail in A. macintoshii. However, Bursey \&Goldberg(2007) recorded that $A$. macintoshii nematodes recovered from frogs in Australo-Papuan region have irregular patterns.

The alimentary canal of A. macintoshii is tubular in shape. The mouth was originally surrounded by three lips and six sensary papillae but no cuticular teeth were observed. The oesophagus has two portions, a long narrow tube which is the oesophageal corpus and a spherical oesophageal bulb. Puga \& Torres(1997) recorded in A. artigasi, an oral opening surrounded by one dorsal and two subventral lips. Each lip with a cuticular flap on anterior ridge, cephalic sense organs consisting of inner circle of six minute papillae and a circle of four outer submedian papillae. Also, they reported that the oesophagus has a small oesophageal corpus, isthmus and bulb provided with a valvular appartus. 
In A. Krausi, the mouth has three lips and four papillae. Oesophagus divided into short pharyngeal portion, elongate corpus, short isthmus and large valved bulb (Bursey et al.,2006). In A. capensis, Baker (1981) observed a large oral opening surrounded by three lips and cephalic extremity with six small inner labial papillae and six outer papillae on the anterior extremity of oesophagus with three short projections covered with thick cuticle and divided into pharyngeal portion of corpus, postrior portion of corpus, isthmus and bulb.

Futhermore, from anterior end at level of pharyngeal portion of oesophagus to hypodermis at the level of oesophageal isthmus, four large muscles extended. He recorded also in A. degraaffi the presence of three lips, six minute inner labial papillae, six small outer papillae and three toothed like projections covered by a thick ring of cuticle at anterior extremity of oesophagus. Moreover, Wharton (1987) and Bursey \& Goldeberg (2007) reported that at the end of the oesophagus (in oesophageal bulb) of Aplectana spp there is an additional valve that prevents the reflux of ingested materials.

A. macintoshii are dioecious nematodes, females are larger in size than males which have curved distal caudal end. Males of Aplectana spp. are usually distinguishable from females by their smaller size, posterior curvature and accessory copulatory structures. Similarly, male A. degraaffi nematodes are smaller than females and have sharp pointed posterior end (Baker, 1981). In A. capensis, Baker (1981) differentiated male from female through its smaller size and slender tapering posterior end while in A. krausi, the tail is conical slender in the posterior two thirds of male, typically bent ventrally, producing a shallow depression around cloaca (Bursey \& Goldberg, 2007).

Furthermore, spicules are needle-shaped and consist of thick cuticular material which surrounds a cytoplasmic core with nerve processes The spicules are formed in a dorsal sac of the cloaca called the spicular pouch (Jamur, 1967). The spicules can be moved back and forth by accessory muscles and during copulation, they inserted in the female vulva. A thickening of the dorsal wall of spicular pouch; the gubernaculum stabilizes the protruded spicule (Smyth, 1994). In Aplectana spp., the spicules are equal in length (Barker, 1981, Bursey \& Golbderg, 2007 and Ramallo et al., 2008).

The gonads of A. macintoshii are tubular with blind end. The other end of the female gonad is attached to the body wall and opens immediately out wards through the vulva, whereas the male gonad opens into the rectum, which thus becomes a typical cloaca. The tubes of the male and female genital system float freely in the fluid of the pseudocoel. Two female genital tubes and single male tube were observed in other Aplectana spp. e.g A. herediaensis ( Bursey et al., 2006) and A. krausi (Bursey \& Goldberg, 2007). In A. macintoshii the genital tubes are twisted around the intestine and this large scale contact probably accelerates the nutritional exchange as explained by Smyth(1994). In comparison to the reproductive system of other nematodes; some trichurids and strongylids have only a single gonad (Grove, 1989). 


\section{REFERENCES}

Anderson, R.C. (1988). Nematode transmission patterns. Parasitol., 74: 30-45.

Azimov, D.V. and Ikramov, E.F. (2001). Fauna and ecology of nematodes of amphibians in Uzbekistan. $4^{\text {th }}$ international Nematol. Symp. Mockea.

Barker, M. (1980). Revision of old world species of the genus Aplictana Railliet \& Henry, 1916 (Nematoda, Cosmocecidae). Bull Mus Natn. Hist. Nat. Paris Ser 4 Sect A 2: 955-998.

Barker, M. (1981). Cosmocercoid nematode parasites from frogs of Southern Africa. Koed. 24:25-32.

Barker, M. (1987). Synopsis of the nematode parasitic in amphibians and reptiles. Mem. Univ. Newfounland Occ. Pap. Biol., 11:1-325.

Bursey, C.R. and Goldberg, S.R. (2007). A new species of Aplectana (Nematod, Cosmocercidae) in Platymantis boulengeri (Anura, Ceratobatrachidae) from Papua new Guinea. Acta parasitology. 52(4): 368-370.

Bursey, C. R.; Goldberg, S.R. and Telford, S.R. (2006). New species of Aplectana (Nematoda: Cosmocercidae) and Mesocoelium monas (Digenea: Brachycoeliidae) in Lepidophyma flavimaculatum (Squmata: Xantusiidae). From Costa Rico. Carib. J. Sci., 42: 164-170.

Farag, H. M. H. (1995). Studies on certain parasitic fauna of Amphibia in Dakahlyia Governorate. M. Sc. Thesis, Zool. Dep. Fac. Sci. Univ., Mansoura, Egypt

Gibbons, L. M. (1986). SEM guide to morphology of nematode parasites of vertebrates. $\mathrm{CAB}$ internation Oxford Uk.

Grove, D. I.(1989). Strongyloidiasis a major round worm infection of man. Taylor and Francis London.

Holmes, R.M.; Bocchiglieri, A.; De Araujo, F.R. and De Silva, R.J. (2008). New records of endoparasites infecting Hypsiboas albopunctatus in a savanna area in Brasilia. Barazil. Rasitol. Res., 102: 621-623.

Jamuar, M.P.(1967). Studies of spermatogenesis in nematode Nippostrongylus brasliensis. Cell. Biolog., 31:381-396.

Levine, N.D. (1980). Nematode parasites of domestic animals and of man. $2^{\text {nd }}$ edit Burgess publishing Co.Minneapolis 
Moravec, F.; Barus, V. and Bysavy, B. (1987). Some parasiticnematodes, excluding heterakidae and Pharyngodonidae from amphibians and reptiles in Egypt. Folia Parasitoloica., 34(3): 255-267

Perry, R.N. and Clarke, A.J. (1981). Hatching mechanism of nematodes. Parasitol., 83: 435-449.

Puga, S. and Torres, P. (1997). Aplectana artigasi (Nematoda: Cosmocercidae) from the frog Eupsophus calcaratus (Anura: Leptodactylidae) in South Chile. Mem. Inst. Oswaldo Cruz, Rio de Janeiro, 92(6): 767-770.

Rago, M.R. and Maharaj, I. R. (2003). Helminthes of the cane toad Bufo marinus from Trinidacl West Indies. Caribbean. Sci., 39(2): 242-245.

Railliet, A. and Henry, A.(1916). Nouvelles resmarques sur les Oxyurides Comptes renduse des seanco de la Soc.Biolog.,79:247-250.

Ramalho, A.C.; da Silva, R.J.; Schwartz, H. and Peres, A. K. (2009). Helminthes from an introduced species (Tupinambia merianae) and two endemic species (Trachylepis atiantica and Amphisbaena ridlyi) from Fernando de Noronha Archipelago , Brazil. Parasitol. 13:1-5.

Ramallo, G.; Bursey, C. R. and Goldberg, S. R. (2008). New Species of Aplectana (Ascaridida:Cosmocercidae)in the toads, Rhinella granulose and Rhinella schneideri (Anura:Bufonidae) from northern Argentina. Parsitol., 94(6):1357-1360.

Saeed, S.; El Barwari, S.E. and Al-Harmni, K.I.(2007). A metazoan parasitological research of some Iraqi Amphibians. Clit. Sayfa (Iar) 4: 337-346.

Smyth, J.A. (1994). Animal parasitology. $3^{\text {rd }}$ edit. Cambridge Univ. New York.

Sommerville, R.I. and Wwinstein, P.P. (1964). Reproductive behaviour of Nematospiroides dubus in vivo and vitro Parasitol. 50: 401-409.

Sterwart, F.H. (1914). Studies in Indian Helminthology. N.1.Res. Indian. Mus., 10: $165-193$.

Travassos, L. (1931). Pesquizas helminthologicas realizadas em Hamburgo. IX En saio monographico da familia Cosmocercidae. Trav., 1925 (Nematoda) Mem. Inst. Oswaldo Cruz. 25: 237-298. 
Wharton, D.A. (1987). A functional biology of nematodes. Croom Helm, London.

Yamagui, S. (1961). Systema helminthum. 111/1 Interic. Publ., New York. London, 1-679 pp.

Yildirimhan, H.S.; Bursey, C.R. and Goldberg, S.R. (2005). Helminth parasites of the Caucasian salamander, Mertensiella caucasica from Turkey. Comp Parasitol., 72:75-87. 